
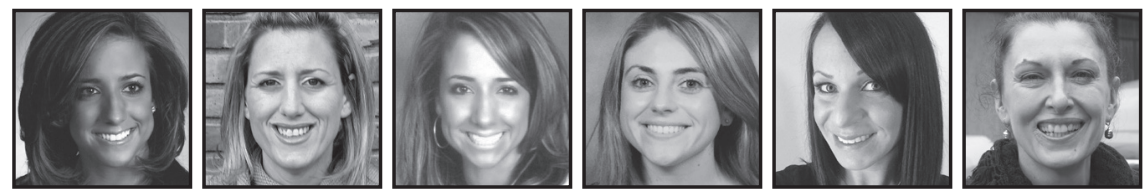

\title{
Doing-It-0urselves as Teacher Researchers: A Collaborative Action Research Approach for Improving Literacy Support at Home
}

Catia Guerra, Beatrice Hanratty, Andreia Onofre, Michele Tedeschi, Laura Wilenchik, and Michele Knobel

\section{ABSTRACT}

This paper describes what a group of teacher researchers learned from conducting an action research project in an urban elementary school serving a multilingual community in the northeastern United States. A key goal of the project was to enhance parents' and caregivers' support of students' literacy development in ways that built on home literacy practices. Teachers' learning included understanding the importance of true collaboration, responding to parent feedback, and teacher-led professional development.

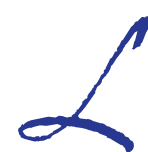

iteracy teachers as researchers have received fairly short shift in recent years, at least within the United States. This is unsurprising, given the enormous emphasis placed on standardized literacy tests and test preparation, on teacher evaluations that use a narrow set of skills to judge instructional quality, and a return to pre-packaged, commercial literacy instruction kits and programs in schools (cf. Cochran-Smith \& Lytle, 2009, 2011; Knobel \& Kalman, in press). In the U.S., even the preparation of reading specialists (teachers certified as advanced experts in the area of reading) typically overlooks the important role teacher research can play in teacher learning and expertise development. None of the International Literacy Association's standards for evaluating the preparation of reading specialists, for example, include conducting teacher research as an element of this role. This is despite 
emphasis within the standards on reading specialists as "leaders" and as deliverers of professional development experiences (ILA, 2015a). Instead, the standards-especially standard 6-emphasize reading "relevant research" by means of meetings and study groups and building the results of this reading into practice (ILA, 2015b). An emphasis on reading specialists consuming, rather than producing, "relevant research," leaves little room for learning how to ask and address teachers' actual questions about immediate instructional and student learning concerns. As such, a key motivating factor in the project described in this paper was to engage a group of reading specialists-in-training in a research production orientation towards literacy-related professional development. This orientation foregrounds teachers' abilities to generate professional development experiences that are meaningful and thoroughly situated within their own contexts, and recognizes their professional knowledge and expertise. This stance requires teachers to become well-qualified researchers in their own right and to understand research from the inside as producers. An insider understanding of research design and processes also means teacher researchers are equipped with criteria for evaluating and critiquing published research literature, rather than perhaps reading study outcomes, and regarding them as "true" and "un-challengeable" (cf. Lankshear \& Knobel, 2011, ch. 8).

This "producers'" orientation towards research is influenced by a growing body of academic work that documents how Do-It-Yourself (DIY) practices shift everyday people from consuming media and goods produced for them, to producing their own in personally and socially satisfying ways. Even more aptly for current purposes, Henry Jenkins (2010) has built on this DIY academic interest and argued for a focus on "Do-It-Ourselves" instead, in order to recognize how we rarely learn something completely on our own. Rather, we make use of in-person or distributed networks of resources and communities of support where "we learn from each other in the process of working together to achieve shared goals" (Jenkins, 2010, p. 233; original emphases). Of course, collaborative approaches to teacher research aren't new, and the kind of project reported here does not break new ground, but under current conditions of decreased teacher autonomy and increased individual teacher accountability and evaluation within U.S. education, a re-emphasis on truly collaborative teacher research is no bad thing.

A "Do-It-Ourselves" orientation also places useful emphasis on teachers being researchers. That is, on them developing a strong sense of what counts as good quality research within education. This includes a sound understanding of research design and how to develop a sound research question, how to frame their project using theory and key concepts, how to collect appropriate and robust data, and how to analyze and interpret it systematically and in relation to past and current developments within 
the field. As such, a "Do-It-Ourselves" orientation foregrounds teachers teaching themselves to be academic researchers by taking primary responsibility for conducting well-informed and well-designed projects.

In what follows, we describe the experiences of, and learning outcomes for, five reading specialists-in-training in one cycle of an ongoing collaborative action research project within an urban school located within a significantly economically depressed city in the northeastern United States. This project was prompted by the school's goal of involving parents and caregivers more actively in their children's learning. It was organized around a teacher study group that included five teachers from this schoolin addition to the five reading specialists-in-training who initially brought the study group together (i.e., 10 teachers in total). Project leaders and participating teachers worked together to develop what became a series of "Family Literacy Nights" aimed at providing concrete resources for parents and caregivers to use at home to support their children's literacy growth. Due to university research review board restrictions, we are unable to report the action research study itself and do not follow the conventions of a research report in this paper. We focus instead on what five novice teacher researchers learned as a result of designing and conducting an action research project and what they gained from taking a "Do-It-Ourselves" approach. In terms of the authorship of this paper, the five teacher researchers are: Beatrice Hanratty, Andreia Onofre, Catia Guerra, Michele Tedeschi, and Laura Wilenchik. Michele Knobel was the consulting university professor for this project.

In what follows, we describe two contexts that directly shaped the "Family Literacy Nights" project. This is followed by a discussion of the study group and how it employed an action research process. The paper closes with a discussion of the outcomes of the initial "Family Literacy Night" and what was learned from the research process itself.

\section{Context}

There are two contexts for this project: one comprises a university Masters-level course, and the other a large, urban school in a significantly low-income area.

The course is part of a Masters of Reading program that prepares teachers to be reading specialists. Teachers enrolled in this course are required to work in groups to develop literacy-focused professional development experiences for teaching colleagues at local schools, and to embed this professional development within a 
collaborative action research design. Collaborative action research is defined in this course in terms of consensually identifying a real problem or question to investigate and address in order to improve or enhance teaching practice and/or student learning experiences or outcomes in some way (texts used include: Altrichter, Posch, \& Somekh, 1993; Lankshear \& Knobel, 2004; McNiff \& Whitehead, 2002). The design of the project itself comprises bringing together a group of classroom teachers to develop a research question to address, framing the study with an appropriate theoretical orientation, collaboratively developing ways of addressing the research question, trialing these and collecting data to help evaluate their effectiveness or suitability, analyzing collected data, using the results of the analysis to inform a new round of addressing the research question, and so on. The first seven weeks of the 15-week course focus explicitly on critiquing the quality of published literacy research, on research design, on using literacy and learning theories to frame research, and on collecting and analyzing data in systematic ways. The remainder of the course entails teacher researcher groups meeting with Michele, the instructor, every two weeks to discuss progress, ask questions, check the systematicity of their data coding, and so on.

This paper focuses on a project by one teacher research group (i.e., Beatrice, Andreia, Catia, Michele, and Laura). Two of the teachers in this group-Andreia and Catia-work in a large elementary school in the northeast of the U.S. (464 students). The majority of students enrolled in this school are Hispanic (44\%) or white non-Hispanic (34\%), with the remainder comprising Asian/Pacific Islander (9\%), Asian (9\%), and Black non-Hispanic (4\%) students. Twenty percent of these students have been assessed as having "limited English proficiency" and the school has developed a very successful Spanish bilingual program. This school became the "host" for the group's professional development project, and a group of five classroom teachers (one teacher from each grade level in the school) volunteered to be part of the project. A recently established goal for this school was to improve home-school communication and parent involvement in supporting their children's learning. At the time, classroom teachers in the host school had been looking for existing parental involvement initiatives to help guide their own initiatives, and this became the springboard for the professional development action research project described in this paper.

Comments from the five classroom teachers who volunteered to be part of this action research study underscored some of the frustrations they were encountering in trying to improve how they interacted and worked with their students' parents. "This has been a challenge at [host school] for years, especially after we have become so well known for our bilingual program," explained Ms. Sagui, a first grade teacher (25 bilingual and general education students). "I find it so challenging to communicate 
with parents who don't speak English and I don't have the tools to communicate with them in their home languages, so I'm stuck," explained Ms. Moore, a fifth grade teacher (23 English language learning students). "Although all of my parents speak English, it is a struggle to get them to help at home, especially with reading in first grade which is such a crucial grade," added Mrs. Rathgeber, a first grade teacher ( 24 general education students). Ms. Casale, a third grade teacher (22 bilingual and general education students) pointed out, "It's hard enough getting bilingual working parents here on Back-to-School night because they don't have anyone to watch the children." The fifth participant, Mrs. Tatarenko, a second grade teacher (22 bilingual and general education students), had always been very involved with the parents of her students, but indicated she was very open to additional suggestions for enhancing this relationship and was interested in sharing her own ideas with others (all comments from initial interviews with participating classroom teachers, September 2014).

\section{A Brief Description of the Action Research Project}

The research question developed collaboratively was: "What happens when teachers provide parents with explicit strategies for supporting at-home literacy learning practices?" The theoretical framing for the study usefully blended Luis Moll's and colleagues' conception of "funds of knowledge" with James Paul Gee's conception of $\mathrm{D} /$ discourses. Funds of knowledge are the cumulative results of family members' lived experiences (at home, at work, within their communities, etc.), their historicity (ethnicity, how things were done in their own families), their ways of doing things, and so on, that collectively serve to maintain the well-being of their family (Esteban-Guitart \& Moll, 2014). This concept is fully grounded in the conviction that "people are competent, they have knowledge, and their life experiences have given them that knowledge" (González, Moll, \& Amanti, 2005, pp. ix-x). The concept, "funds of knowledge," was developed in direct response to the construction of poor and minority students by schools as "deficient" when they came to school (e.g., they "lack" English, they "lack" academic ability or motivation, etc.). A focus on "funds of knowledge" requires researchers and educators to attend to the rich stores of knowledge, ideas, and practices to be found in homes and to use them as a foundation for student learning.

Gee's (2015) theory of "big D" Discourses casts Discourses as "ways of behaving, interacting, valuing, thinking, believing, speaking, and, often, reading and writing, that are accepted as instantiations of particular identities ... by specific groups" (p. 4). "Big D" Discourses help to explain how society is socially shaped and constructed and 
how our own ways of being in the world are informed by these socially recognized and patterned ways of being and doing. Gee distinguishes two types of Discourses: primary and secondary. The primary Discourse is typically the Discourse one is "born into" and experiences at home (Gee, 2015). Secondary Discourses are encountered outside the home or family and describe forms of being and doing within social institutions, such as schools (Gee, 2015). The secondary Discourses that students encounter in schools typically are part of dominant Discourses; that is, the ways of acting, interacting, valuing, thinking, speaking, accruing success, and so on that are shaped, constructed, judged, and maintained by the group who holds the most power within a given society (Gee, 2015). Thus, it follows that children whose primary Discourse bears close resemblance to the secondary Discourses of schooling are, by default, going to have an "easier" time at school in terms of being the "right" kinds of students and doing the "right" kind of learning work. According to this theory, students whose primary Discourses differ quite markedly from the secondary Discourses of schooling often find school itself puzzling or contradictory, which can impinge negatively on their learning (see related accounts in Heath, 1983; Lareau, 2011).

Bringing together "funds of knowledge" and Discourses meant that the action research project itself necessarily emphasized the importance of not simply acknowledging children's "background knowledge," but worked to identify what funds of knowledge they had access to at home and how these could be explicitly recognized and valued in classrooms in order to help students operate more effectively in the secondary Discourse of their school (cf. Fiano, 2013; Hedges, 2011; Moje et al., 2004). Gee (2015) explains it is not enough for students to adapt to and learn school-based Discourse, but that the school must include and value the students' primary Discourses as well. The creation of open, reciprocal relationships between families and teachers enables conversations about parents' own lived experiences of schooling when they were young, about learning to read and write, and how literacy practices are used in their everyday lives.

As a reminder, due to Institutional Review Board requirements, this paper cannot be presented as a research study report per se, but as a description of what a group of teacher researchers learned about professional development and the research process as the result of conducting collaborative action research designed to involve parents more in supporting their children's literacy learning at home. In what follows, we describe the project and its outcomes first, then what was learned by the teacher researchers. 
To begin, initial information about parent-teacher communication and relationships was collected by means of two school-wide Likert-scale type surveys: one targeting teachers and the other targeting parents and caregivers. Responses from the 36 teacher surveys and the 115 returned parent surveys suggested that most teachers and parents agreed that parental involvement is important in enhancing student achievement at school. Where the two groups did not agree concerned knowing how to offer effective support at home. Parents responded that they did know how to help, while the majority of teachers responded that parents did not know how to help students with schoolwork at home. Addressing this disconnect therefore became an initial point of focus for this project, with a focus on literacy making the project manageable.

The project group met every Tuesday afternoon for 90 minutes over 14 weeks to discuss theory and research, and to identify and plan practical ideas for working directly with families. To begin, the group read academic articles concerning funds of knowledge research, as well as research on the relationship between parental involvement in their child's learning at home and student achievement at school (e.g., Dearing, Kreider, Simpkins, \& Weiss, 2006; Jeynes, 2012; Reese \& Gallimore, 2000; Robbins \& Searby, 2013). The group decided a "Family Literacy Night" in mid-November would be a manageable initial response to the research question driving this project. The evening itself would include presentations from the classroom teachers regarding how to support literacy learning at home and discussions with parents about what they - the parents - felt worked well already. This became the first cycle of their project and the focus of this paper.

The collaborative nature of this project meant the reading specialists-in-training initially supplied a range of resources to help generate ideas and to encourage the five classroom teachers to begin looking for and developing their own ideas. Thus, teachers were initially directed towards ReadingRockets.org and its wealth of articles and practical videos about literacy teaching and learning, including teaching in bilingual contexts and articles written for parents. TeachersPayTeachers.com, with its teachergenerated lesson ideas, plans, and resources, was also an initial recommendation. The group established a collaborative Pinterest.com board, and the classroom teachers soon became active "pinners" of relevant ideas and resources to this site. Weekly meetings focused on how to best help parents support their children's literacy learning at home, taking into account the importance of including as much as possible of each family's funds of knowledge. 


\section{"First Cycle" Project Outcomes}

It soon became apparent to the group members that if they wanted to take families' funds of knowledge seriously, they needed to hold more than one Family Literacy Night. Thus, it was decided that the first event would act as an introduction to a series of nights that would provide space for parents to share information about home literacy practices and for accessing strategies that built on these practices in support of student literacy learning at home.

One unexpected outcome of this project was the interest and commitment it inspired in others outside the group. The principal of the host school, for example, became a very active supporter of the initiative and attended the inaugural Family Literacy Night, formally welcoming and then later chatting with parents. Four additional classroom teachers from the host school, including the school's English language teacher, became involved as well. The teacher researchers themselves were quite surprised at how much interest was shown by others, and how much support and help was voluntarily offered in what quickly became a very supportive network.

The first Family Literacy Night was well advertised to all parents and students. It was held mid-week in late October 2014, and 46 families attended. One parent who attended had not been able to make it to school events before and described how her Grade 3 daughter had come home, checked her mother's work schedule to ascertain her mother wouldn't be working the evening of the first Family Literacy Night and that she therefore could-and had to-attend. The action research group provided childminding services as part of this family-focused event in order to maximize parents' and caregivers' attendance. Two classroom teachers from the group designed a range of craft activities for the children in their care for the 75 minutes (i.e., 6:00-7:15 p.m.) of the first Family Literacy Night, and found themselves watching over 91 children. The parents and caregivers themselves were seated at tables, facing a screen and the classroom teacher presenters. Additional tables held relevant materials (e.g., a graph emphasizing the importance of reading to children for 20 minutes a day; a list of useful apps; a summary of text genres and their features). Many of these handouts were translated into Spanish by teachers involved in the project, including teachers who were not Spanish speakers themselves, but who made use of Google Translate and other online resources.

The classroom teachers opened the event with the quote: "Children are made readers on the laps of their parents" (attributed to Emilie Buchwald, an award-winning children's author). This quote was a motif for the night, and the Parents and Teachers 
Association had printed up bookmarks carrying this slogan to be sent home with attendees. Parents also watched a video titled, "The Power of Reading to Your Children" (VideoNow Productions, 2011). The teachers wanted to share accessible, researchinformed resources with parents, and video content addressed reading and book awareness with very young children (aged three months and up), oral language and interactions, how parents shouldn't worry about how well they themselves read, and that any interaction around texts will benefit children. Participating teachers quietly helped with simultaneously translating the video's English voicetrack for small groups of Spanish-speaking parents. A range of useful websites and apps was also presented (building on an awareness that children made use of their parents' smartphones at times to play games, etc.), including an overview of the two digital systems in place in the school-Accelerate Reader and RAZ Kids-to better familiarize parents with both systems.

A key point emphasized throughout the night was the importance of reading to children, even if they could read already, in order to model effective reading, enthusiasm for reading, and for discussing important elements within the text (e.g., character development and how it related to children's own decision-making processes). Another key point conveyed to parents was that it didn't matter what parents and children read together at home, either, and that texts could include everyday texts found at home, like recipe books, religious materials, magazines, newspapers from their parents' country of origin, and so on. This alone seemed to be advice parents found valuable, so that when Mrs. Tatarenko explained, "Reading together is a shared event that can occur in any language," one parent asked, "So, it's okay to read in two languages to my child?" and was met with strong confirmation from the teachers. Teachers also repeatedly encouraged parents to make reading a part of normal, daily life and to relate the texts they read together to the child's and family's daily life experiences as much as possible.

The portion of the evening that really drew parents and caregivers into a conversation with the teachers occurred when parents were presented with a number of vignettes of struggling readers. The cases (from Leipzig, 2001) were used to spark a lively discussion concerning what each reader needed in terms of additional reading support (e.g., support with understanding what was being read, decoding unfamiliar words, addressing frustration and reading fluency). Parents and caregivers were very engaged, especially when they were able to identify key problem areas themselves and collectively discuss ways of addressing them at home. They commented on how they recognized some of the difficulties described in the vignettes in their own children (e.g., frustration with getting the text to make sense, expressing loathing towards reading, avoiding reading altogether). Parents and caregivers were encouraged to identify areas where 
their own child could use some more support and sign up for a related workshop in the next Family Literacy Night event (scheduled for early December).

The teachers wrapped up this first Family Literacy Night-and the first cycle of their action research project-by passing out an eight-item survey (available in Spanish and English) that asked attendees to rate possible future literacy workshops (e.g., on comprehension, rhymes and poetry, bilingual reading aloud, promoting reading interest) based on level of interest/need. The workshops were described briefly, and it was explained how the workshop leader would provide each group with a set of practical strategies and the parents would work directly with their child or children right then and there to practice these strategies, before regrouping and discussing how things went, what they learned about helping their child, and so on. The survey also asked about the primary language spoken at home (languages identified were: English, Spanish, Polish, Gujarati, and Chinese) and for feedback on the evening. Forty surveys were completed in English and six in Spanish.

Feedback was overwhelmingly positive. For example:

- "Please go around to other elementary schools in the district and do this literacy night!"

- "Fantastic! I love that you are having 'Literacy Nights.' Much needed and timely. I'd like to help my daughter with the stress of taking and passing her [Accelerated Reader] quizzes."

- "Lots of great tips were provided at this meeting to continue to help my child with the love of reading."

- "I love the list of websites and apps!"

While families were leaving, a number of them were heard saying to each other: "We have to come back December third." One teacher researcher later overheard two students in her Grade 3 class discussing which literacy workshop their parents would be participating in on the next Family Literacy Night.

\section{Professional Development Outcomes}

All participating classroom teachers agreed that the project group was an essential component of their professional development, with all of them agreeing they'd collectively learned a significant amount about how to better support families and 
literacy development at home. In addition, they agreed that the group itself served as a valuable support network. As Mrs. Casale explained, "It's comforting to know that you are not the only one dealing with these issues." The teachers especially appreciated how their meetings enabled them to pool their ideas and expertise:

Having regular meetings allowed us to share our individual input and ideas as well as gain a different perspective from listening to each other. We became focused on our common goal and were then able to work together to move forward. (Personal communication, Mrs. Tatarenko)

"Collaboration" was certainly a strong theme for the group members. This included strengthening their collaborative relationships with one another, as well as with specialists outside the group, such as the host school's English language teacher.

All the teachers felt strongly that they'd been able to meet their goals for the first cycle of their project, and were very pleased with the outcomes of their initial Family Literacy Night in terms of how it very much opened up a dialogue between teachers and parents about how to best support students' literacy development. Mrs. Sagui appreciated how the group's goals and plans ended in real action:

Thinking back to our surveys in September, we identified "lack of family involvement" as a big issue in our school. After working together and implementing [our first] Family Literacy Night, all of the things we envisioned we were able to achieve. We were truly able to connect a need to an action. (Concluding group interview, November 25, 2014)

Mrs. Tatarenko alluded to the negative media their area regularly attracted with respect to schooling, teachers, and students, and emphasized instead how their initial Family Literacy Night really helped them to address such misperceptions:

By implementing Family Literacy Night events we are showing that we do not stop caring about our students and their families at 3:00 p.m. By taking on this challenge, we are actively working to erase the stigma against schools and teachers that negative publicity has created. We are fighting the negative and gaining respect back for the profession. We are showing parents that [host school] is a warm and caring place where the whole family is welcomed. (Concluding group interview, November 25, 2014) 
While the extent to which literacy support at home and at school impacts positively on students' school achievement remains to be seen, these comments and outcomes certainly resonate with the "Do-It-Ourselves" ethic of this project that emphasizes teachers taking on real problems within their own teaching contexts and developing ways to address them. They also resonate with the ideals of enhanced professionalism, of grass-roots approaches to professional learning, and of better support to student literacy learning as a result of professional development initiatives.

Project fieldnotes are replete with group discussion of the connection between theory, research, and practice. As one example among many, the group's plans for the workshops for the second Literacy Night deliberately included parents working directly with their own children to practice new strategies or methods for supporting reading. This was influenced by reading about effective approaches to professional development (e.g., Darling-Hammond \& McLaughlin, 2011), and they wanted to engage parents in similar development processes in order to help maximize parents' own insights and learning.

Documenting the study formally finished at the end of November 2014. The action research group continued to meet each week after the First Literacy Night. Part of its ongoing work has included sending "Thank You" cards to the families who attended the first Family Literacy Night to show how appreciative these teachers were of their commitment to wanting to work together regarding their child's literacy learning. Subsequent meetings have been devoted to finalizing plans for the second and third Literacy Nights. As mentioned earlier, the second night focused on delivering practical workshops, and the third was a response to parents' significant interest in promoting reading interest. This third night-held in early January 2015-was focused simply on enjoying reading and took the form of a pajama party, with everyone coming in their pajamas and teachers modeling how to read in engaging ways, how to discuss books in ways that focused on meaning making, and so on. The Parents and Teacher Association provided hot chocolate and sweet snacks for this third evening. Clearly the group was committed to ongoing cycles of Family Literacy Nights, with each cycle informed by teachers' reading and reflection, parents' feedback and requests, and students' literacy needs.

The group also plans to work on accessing more translators, too-especially speakers of Polish, Chinese, and Gujarati. As Mrs. Casale put it, "It's our goal to support all families. However, our ability to support linguistically diverse families is significantly impaired due to our lack of multilingual translators" (concluding group interview, November 25, 2014). Indeed, another pattern found in the data was a shared 
commitment to "communicative flexibility" which was defined in terms of multiple modalities of communication and involvement made available to all families. Clearly, the teachers in this group intend to retain this commitment as they find more and more ways of communicating effectively with school families.

To sum up, outcomes to date suggest that the action research project successfully met its initial goals and opened up more possibilities for parents to become involved in their children's literacy learning in ways that respected home practices, while ensuring access to school practices associated with improved literacy learning in school. Interesting next steps would be to document any noticeable improvements in students' literacy practices at school that can be attributed to home support.

\section{Teacher Researchers' Learning Outcomes}

In this paper we've aimed at showing how at least one cycle of the action research process of planning, implementation, evaluation, then building on original plans, and so on was practiced by a group of reading specialists-in-training intent on becoming teacher researchers. Participating classroom teachers also collected data and reflected on findings, but our focus here is on the five reading specialists-in-training. We've tried to show the importance of having a strong relationship between theory and action, and of using extant research to guide professional learning, while at the same time valuing teachers' existing knowledge and expertise as they made decisions about what was most needed in terms of working with families.

The five teacher researchers who spearheaded this project really did enact a "Do-It-Ourselves" orientation to teachers being researchers. As their advisor who met with them every two weeks in the second half of the semester-long course, Michele noticed how they carefully framed their study theoretically, collaboratively developed a useful guiding question, designed their data collection and analysis processes as cycles, and how they used the results of their data coding to inform what they did next. Early data analysis patterns focused on time issues, for example, but as the project progressed, these fell away and new patterns-like needing to be communicatively flexible in reaching out to parents, and the importance of collaboration-came to the fore as the group allocated dedicated time to work on its project and read up on ways of including parents more actively in their children's literacy learning. As Beatrice explained, collecting data systematically and then analyzing these data was "most helpful throughout the process" and that "the project itself helped me realize 
the impact that teachers can have by putting theory into practice" (e-mail to course instructor, December 2014).

The group members also learned about the importance of time commitment from all participants, including themselves. As Laura explained,

I would have to say that meeting every week face to face was crucial for our study group (and perhaps any study group.) Yes, online meetings and google docs can be successful for communication; however, I truly feel that because each and every one of us met every Tuesday at the same time is why we were all such a good team and on the same page. (E-mail to course instructor, December 2014)

These meetings meant that three of the teacher researchers needed to drive an hour each way to attend once their own teaching day had finished. This commitment was mirrored in the participating classroom teachers, too: "The teachers never used any excuses (holidays, meetings, school work, etc.) to get out of the meetings. They were very serious about that time slot every Tuesday afternoon and always showed up ready to work" (Catia, e-mail to course instructor, December 2014).

This group of teacher researchers also appreciated the extent to which they and the participating classroom teachers were truly able to collaborate in addressing a problem that was very real to them, even when in the beginning, this required some tricky navigation between "when to support the teachers and when to let them work through situations" (Beatrice, e-mail to course instructor, December 2014). Indeed, the idea of collaborative action research instigated and conducted solely by teachers as a truly viable alternative to top-down, one-size-fits all professional development experiences was a significant learning point for at least one member of the group. As Michele (Tedeschi) wrote:

The major take away I gained from participating in the research process is that teachers must actively initiate action research opportunities. Prior to completing this research I was misguided in the sense that I believed that teachers were not given opportunities to facilitate large-scale change. Through completing this study I have learned it is not necessary for teachers to be granted these opportunities. Rather, it is entirely possible for teachers to create their own opportunities. Initially I was nervous about involving the principal at our host school. However, the support and accolades we received from the principal now cause me to wonder why administrators would not support programs for school-wide improvement. 
Through working with our project group I have learned that when teachers work together and unify under a common voice they are able to enact significant change.

Collectively, what these teacher researchers learned from designing and implementing their own well-designed research project resonates with the International Literacy Association's expectations regarding teacher leaders (ILA, 2015a), but adds an important dimension of agency and production to the description of teacher "leaders" given in the standards for reading specialists.

\section{Conclusion}

The importance of a Do-It-Ourselves orientation towards teacher research, especially when it is conducted as part of university coursework, cannot be underestimated. In this particular case, the teacher researchers were apprenticed to being academic researchers and held to high standards in terms of designing and reporting their project. Their instructor has every confidence that each of them is now well able to produce independent, sound qualitative research in their respective school settings. The project focus took a real-world problem and resulted in very concrete action, informed by theory and extant research, while at the same time was tailored specifically to the families of the host school. The action research project became a rich context for professional learning and growth. This meets the ideals posed by Ravitch (2014), who argues that the

promise of practitioner-driven research is that the learning emerges from local, situated inquiry, the kind of inquiry that leads practitioners to engage in evidencebased practice-in a reinvigorated sense of that term, meaning that it is grounded in our own contexts, practices, and settings. (p. 6)

But even more than this, the teacher researchers and their group of classroom teachers learned the benefits to be gained from taking a problem and making it their own to resolve, and working together to do so. 


\section{References}

Altrichter, H., Posch, P., \& Somekh, B. (1993). Teachers investigate their work: An introduction to the methods of action research. London: Routledge.

Cochran-Smith, M., \& Lytle, S. (2009). Inquiry as stance: Practitioner research for the next generation. New York: Teachers College Press.

Cochran-Smith, M., \& Lytle, S. (2011). Changing perspectives on practitioner research. LEARNING Landscapes, 4(2), 17-24.

Darling-Hammond, L., \& McLaughlin, M.W. (2011). Policies that support professional development in an era of reform. Phi Delta Kappan, 92(6), 81-92.

Dearing, E., Kreider, H., Simpkins, S., \& Weiss, H.B. (2006). Family involvement in school and low-income children's literacy: Longitudinal associations between and within families. Journal of Educational Psychology, 98(1), 653-664.

Esteban-Guitart, M., \& Moll, L. (2014). Funds of identity: A new concept based on the funds of knowledge approach. Culture \& Psychology, 20(1), 31-48.

Fiano, D. (2013). Primary discourse and expressive oral language in a kindergarten student. Reading Research Quarterly, 49(1), 61-84.

Gee, J. (2015). Social linguistics and literacies: Ideology in discourses (5th ed.). London: Routledge.

González, N., Moll, L., \& Amanti, C. (2005). Funds of knowledge: Theorizing practices in households, communities and classrooms. Mahwah, NJ: Lawrence Erlbaum.

Heath, S.B. (1983). Ways with words: Language, life and work in communities and classrooms. Cambridge, MA: Cambridge University Press.

Hedges, G. (2011). Rethinking Sponge Bob and Ninja Turtles: Popular culture as funds of knowledge for curriculum co-construction. Australasian Journal of Early Childhood, 36(1), 25-29.
ILA (International Literacy Association). (2015a). Standards for Reading ProfessionalsRevised 2010. Retrieved from: http:// literacyworldwide.org/get-resources/ standards/standards-for-reading-pro fessionals/standards-2010-role-5

ILA (International Literacy Association). (2015b). Standard 6. Standards for Reading Professionals-Revised 2010. Retrieved from: http://literacyworldwide. org/get-resources/standards/standardsfor-reading-professionals/standards -2010-standard-6

Jenkins, H. (2010). Afterword. In M. Knobel \& C. Lankshear (Eds.), DIY media: Creating, sharing and learning with new technologies (pp. 231254). New York: Peter Lang.

Jeynes, W.H. (2012). A meta-analysis of the efficacy of different types of parental involvement programs for urban students. Education and Urban Society, 47(4), 706-742.

Knobel, M., \& Kalman, J. (in press). New literacies and teacher learning: Professional development and the digital turn. New York: Peter Lang.

Lankshear, C., \& Knobel, M. (2004). A handbook for teacher research. Maidenhead, UK: Open University Press.

Lankshear, C., \& Knobel, M. (2011). New literacies. Maidenhead, UK: Open University Press.

Lareau, A. (2011). Unequal childhoods: Class, race, and family life, with an update a decade later. Berkeley, CA: University of California Press.

Leipzig, D. (2001). Struggling reader portraits. Retrieved from http://www.readingrockets. org/article/portraits-struggling-readers

McNiff, J., \& Whitehead, J. (2002). Action research: Principles and practice (2nd ed.). New York: RoutledgeFalmer.

Moje, E., Ciechanowski, K., Kramer, K., Ellis, L., Carrillo, R., \& Collazo, T. (2004). Working toward third space in content area literacy: An examination of everyday funds of knowledge and Discourse. Reading Research Quarterly, 39(1), 38-70. 
Ravitch, S. (2014). The transformative power of taking an inquiry stance on practice: Practitioner research as narrative and counter-narrative. Perspectives on Urban Education, 11(1), 1-10.

Reese, L., \& Gallimore, R. (2000). Immigrant Latinos' cultural model of literacy development: An evolving perspective on homeschool discontinuities. American Journal of Education, 108(2), 103-134.
Robbins, C., \& Searby, L. (2013). Exploring parental involvement strategies utilized by middle school interdisciplinary teams. School Community Journal, 23(2), 113-136.

VideoNow Productions. (2011). The power of reading to your children. Video. Retrieved from https://www.youtube.com/ watch? $v=8 I$ WKWWmlcRA

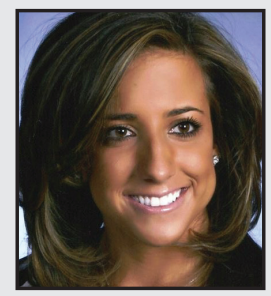

Catia Guerra received a B.A. in Family Child Studies and Elementary Education Certification in grades $\mathrm{K}-5$, and a certification in Middle School English and Middle School Science in grades 6-8, along with a Masters Degree in Reading with a certification as a Reading Specialist from Montclair State University (New Jersey). She is currently in her fifth year of teaching second grade at Elementary School 13 in Clifton, NJ. A strong advocate for early literacy and school readiness for children, her professional interests focus on enhancing parents' and caregivers' support of students' literacy development in ways that build on home literacy practices.

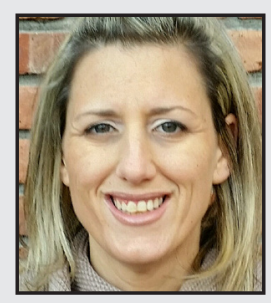

Beatrice Hanratty is an elementary school teacher with the Saddle Brook School District and an assistant instructor for the Summer Literacy Program for Reading Specialist candidates at Montclair State University. She earned a Bachelor of Arts degree in Early Childhood Education K-6, MA in Reading with Reading Specialist and Supervisory certifications from Montclair State University. She was a recipient of the Joseph F. Brunner Research Award from this same university in recognition of her outstanding research in the field of Literacy Education. This is her fifth year teaching and she is passionate about helping students and colleagues build a love for literacy. 


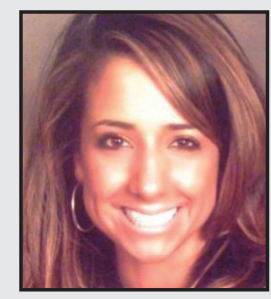

Andreia Onofre is a third grade teacher at School Number Thirteen in Clifton, New Jersey. Her primary areas of teaching are general education students at the elementary level. Andreia graduated from Montclair State University with a Bachelor of Arts degree in Family and Child Studies with a certification in grades K-5 and Middle School English and a Masters Degree in Reading with a certification as a Reading Specialist. She joined the Clifton Public School district in 2011. She was awarded the Joseph Brunner Research Award for a group academic research that explored the effect of educating families on reading strategies and skills appropriate for and geared for their child.

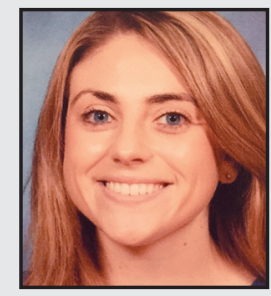

Michele Tedeschi serves as an Elementary Education teacher within a New Jersey public school district. A graduate of Montclair State University, she holds a Master's degree in Reading. She is currently involved in supporting the literacy needs of individual students ranging in age from preschool through to adults. Outside of her role as an educator, she continues to explore her passion for literacy through actively participating in professional learning communities focused on strengthening literacy practices.

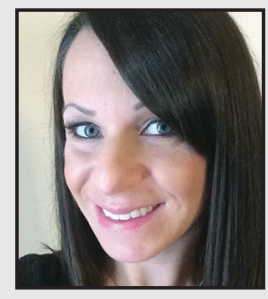

Laura Wilenchik is a graduate of Montclair State University (USA). She majored in Family and Child Studies with a concentration in K-5 and received her Bachelor's degree in 2011. Laura continued her studies and attended Graduate school, where she majored in Reading and simultaneously obtained her Reading Specialist certification. Following the completion of her Master's degree, Laura also completed her Supervisor certification. She is currently employed as a Kindergarten teacher at School \#29 in Paterson, New Jersey (U.S.A.). Thus far, Laura has been involved in the organization and implementation of two Family Literacy Nights at her school. 


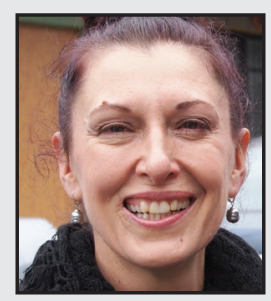

Michele Knobel is Professor of Literacy within the Department of Early Childhood, Elementary and Literacy Education at Montclair State University (USA). She has been involved in supporting preservice and inservice teachers' literacy and digital technology learning in the United States, Australia, Mexico, and Canada. Her publications include New Literacies (Open University Press, 2011, 3rd ed.; with Colin Lankshear), A New Literacies Reader (Peter Lang, 2013; edited with Colin Lankshear), and A Handbook for Teacher Research (2004, with Colin Lankshear). 